\title{
Geochemistry, Hydrothermal alteration and Ore mineralogy of Skarn Mineralization at Wethey-Pheshey area, Thabeikkyin Township, Mandalay Region, Myanmar
}

\author{
Toe Naing Oo*1, Lucas Donny Setijadji ${ }^{2}$, I Wayan Warmada ${ }^{2}$, and Than Than Oo ${ }^{1}$ \\ ${ }^{1}$ Department of Geology, Dagon University, Yangon, Myanmar \\ ${ }^{2}$ Department of Geological Engineering, Gadjah Mada University, Yogyakarta, Indonesia
}

\begin{abstract}
Wethey-Pheshy area is located $80 \mathrm{~km}$ north of Mandalay at Thabeikkyin Township, Mandalay Region. X-ray Diffraction (XRD) Analysis and Inductively Coupled Plasma Mass Spectrometry (ICP-MS) were applied in this study. Geochemical studies on the host rocks indicate that major and minor oxides compositions of metamorphic rocks show some degree of variation. $\mathrm{CaO}, \mathrm{MgO}, \mathrm{FeO}, \mathrm{TiO}_{2}$ and $\mathrm{P}_{2} \mathrm{O}_{5}$ concentration of the metamorphic rock samples show a coherent negative correlation with $\mathrm{SiO}_{2}$ whereas $\mathrm{Na}_{2} \mathrm{O}$ is positively correlated with $\mathrm{SiO}_{2}$. The metamorphic rocks are strongly enriched in light rare earth elements (LREE) and relatively depleted in heavy rare earth element (HREE). The depleted Eu-nomalies in the chondrite-normalized REE diagrams indicate a plagioclase-depleted Eu crustal source or fractionation during magmatic differentiation. Intrusion of granitic rocks in the diopside marble caused the base metal ore mineralization and associated skarn alterations. Granite shows the sub-alkaline nature and peraluminous character. It is identified as I-type granite (magnetite series) developed in the volcanic arc setting. Hydrothermal alteration types associated with gold and skarn mineralization in the study area include calc-silicate alteration, propylitization, sericitization (argillitization) and hematization. Based on the nature and characteristics of host rocks, mineralization and alteration style and geochemical characteristics in the study area is identified as intrusion-related skarn mineralization. Common ore minerals include chalcopyrite, galena, sphalerite, pyrite, gold and Fe-oxides.
\end{abstract}

Keywords: Wethey-Pheshey area · Skarn · Mineralization · Hydrotermal alteration · Geochemistry $\cdot$ Myanmar.

\section{INTRODUCTION}

Wethey-Pheshey area in Thabeikkyin Township is well-known for the occurrences of gold deposit and some varieties of gemstones such as ruby and sapphire. The investigated area lies at the Mogok Metamorphic Belt (Searl and Haq, 1964) and it also lies at the western margin of Shan Highland, and to the west is central lowland. Primary sulfide ore veins containing gold are hosted in marble, calc-silicate rock and biotite microgranite or leucogranite.

\footnotetext{
${ }^{*}$ Corresponding author: T.N. OO, Department of Geology, Dagon University, Yangon, Myanmar. E-mail: mcube201010@gmail.com
}

There are also occurrences of skarn related mineralization in the Kwinthonze gold prospect area. Acid igneous rock of the Gabaing granite massive intruded into the Mogok Metamorphic Belt in the north of the area. Possible skarn zones have been identified in the contact areas of altered marbles and a syenitic intrusive stock. The primary gold mineralization observed in the prospect area occurs as goldbearing limonitic quartz vein in a sequence of metasediments. The purpose of this research is to understand the geochemistry and hydrothermal alteration of skarn mineralization at Wethey-Pheshey area. 


\section{Geologic Setting}

The geological setting of Mogok Metamorphic Belt (MMB) is shown in Figure 1. To the north, Mogok Metamorphic Belt (MMB) is bounded by a left lateral Momike Fault in Western Yunnan, China. To the west, the MMB is separated by Irrawaddy Formation and the right lateral strike slip fault (Sagaing Fault by Swe, 1972). The general structural trend of the study area is nearly N-S. The regional structures of the metamorphic rocks are dipping to the east. To the north and south, rock units of MMB were intruded by igneous rocks. The main igneous unit in the study area is biotite microgranite (Khabaing granite) and the metamorphic rocks (marble, calc-silicate and gneiss). The emplacement age of Khabaing granite which intruded into the marble is Miocene (Zaw et al., 2014).

\section{RESEARCH METHODS}

Microscopic examination of polish sections were carried out to describe the mineralogy of the gold ore deposits. Chemical composition of the rock and ores were analyzed by Inductively Coupled Plasma Mass Spectroscopy (ICP-MS) and Inductively Coupled Plasma Atomic Emission Spectroscopy (ICP-AES). Loss on ignition (LOI) was measured for all samples to be analyzed by ICP-MS technique. Samples for major, minor and rare earth geochemistry were prepared and analyzed at Activation Laboratories (Actlabs), Ontario, Canada. Bulk rock powdered and clay fraction samples analysis were carried out by using XRD, at Faculty of Engineering, Geological Engineering Department, Gadjah Mada University, Indonesia.

\section{Results AND Discussion}

\subsection{Rock geochemistry}

\section{Major and trace element composition}

The major and minor elements content of the metamorphic rocks and associated rock samples show slight variation inside the same suite. The $\mathrm{SiO}_{2}$ contents in all the metamorphic rocks range from 45 to $70 \mathrm{wt} . \%$. The $\mathrm{MgO}$ compositions are mostly in the range of 0.29 to $2.59 \mathrm{wt} . \%$ with the exception of (KW-7) which contain up to $10 \mathrm{wt} . \%$ (Figure 2). $\mathrm{K}_{2} \mathrm{O}$ composition has a range from 0.98 to $2.2 \mathrm{wt} . \%$. The $\mathrm{Fe}_{2} \mathrm{O}_{3}$ concentration has a range of 3.01 to $7.85 \mathrm{wt} . \%$. The $\mathrm{Al}_{2} \mathrm{O}_{3}$ has a wide range between 13.97 and
18.97 wt.\%. The $\mathrm{P}_{2} \mathrm{O}_{5}, \mathrm{Na}_{2} \mathrm{O}$, and $\mathrm{CaO}$ compositions also have wide range of 0.1 to $0.2,2.89$ -3.2, and 2.3--6.95 wt.\% respectively. The $\mathrm{TiO}_{2}$ composition has a range of 0.49 to $1.2 \mathrm{wt} . \%$. According to the Harker diagram the variation of $\mathrm{SiO}_{2}$ with other major and minor elements are illustrated in (Figure 2). On the diagram, $\mathrm{CaO}, \mathrm{MgO}$ and $\mathrm{FeO}$ concentration of the metamorphic rock samples show a coherent negative correlation with $\mathrm{SiO}_{2}$. $\mathrm{CaO}$, and to a lesser extent, $\mathrm{TiO}_{2}$ and $\mathrm{P}_{2} \mathrm{O}_{5}$ also show a negative correlation with $\mathrm{SiO}_{2}$. The $\mathrm{Na}_{2} \mathrm{O}$ is positively correlated with $\mathrm{SiO}_{2}$ due to fractional crystallization.

\section{Rare earth element (REE) geochemistry}

The REE concentrations of the metamorphic rocks from Wethey-Pheshey area were normalized to chondrite meteorite and primitive mantle. Normalization used the schemes of Nakamura (1974) and Sun and Mc Donough (1989).

Chondrite-normalized REE distribution patterns for the metamorphic rocks and associated granitic rocks are presented in (Figure 3a). Samples show gradient in the LREE side and parallel in the HREE side with strongly fractionated pattern. The metamorphic rocks are strongly enriched in light rare earth elements (LREE) and relatively depleted in heavy rare earth element (HREE). LREE enrichment reaches 10 to 1000 times of the chondritic meteorite level. The strong enrichment is more pronounced in granite (KW-1), biotite gneiss (KW-2), calc silicate rock (KW-7) and calc-silicate rock (KW9). HREE show chondrite-normalized pattern in most sample and slight enrichment is observed in ore with marble (KW-3).

Moderate to strong negative $\mathrm{Eu}$ anomalies was observed in some samples, especially in biotite gneiss (KW-2), ore with marble (KW-3), ore with marble (KW-4), marble (KW-8), and marble (KW-10) because these plotting samples lie below the general trend. In contrast, two samples (ore with marble $\mathrm{KW}-5$ and marbleKW-6) are characterized by strong Eu-positive anomaly because of plotting sample KW-5 and KW-6 lie above the general trend. The depleted Eu-nomalies in the chondrite-normalized REE diagrams indicate a plagioclase-depleted $\mathrm{Eu}$ crustal source or fractionation during magmatic differentiation.

On the normalized diagram, the multi elements diagram of metamorphic rocks are 


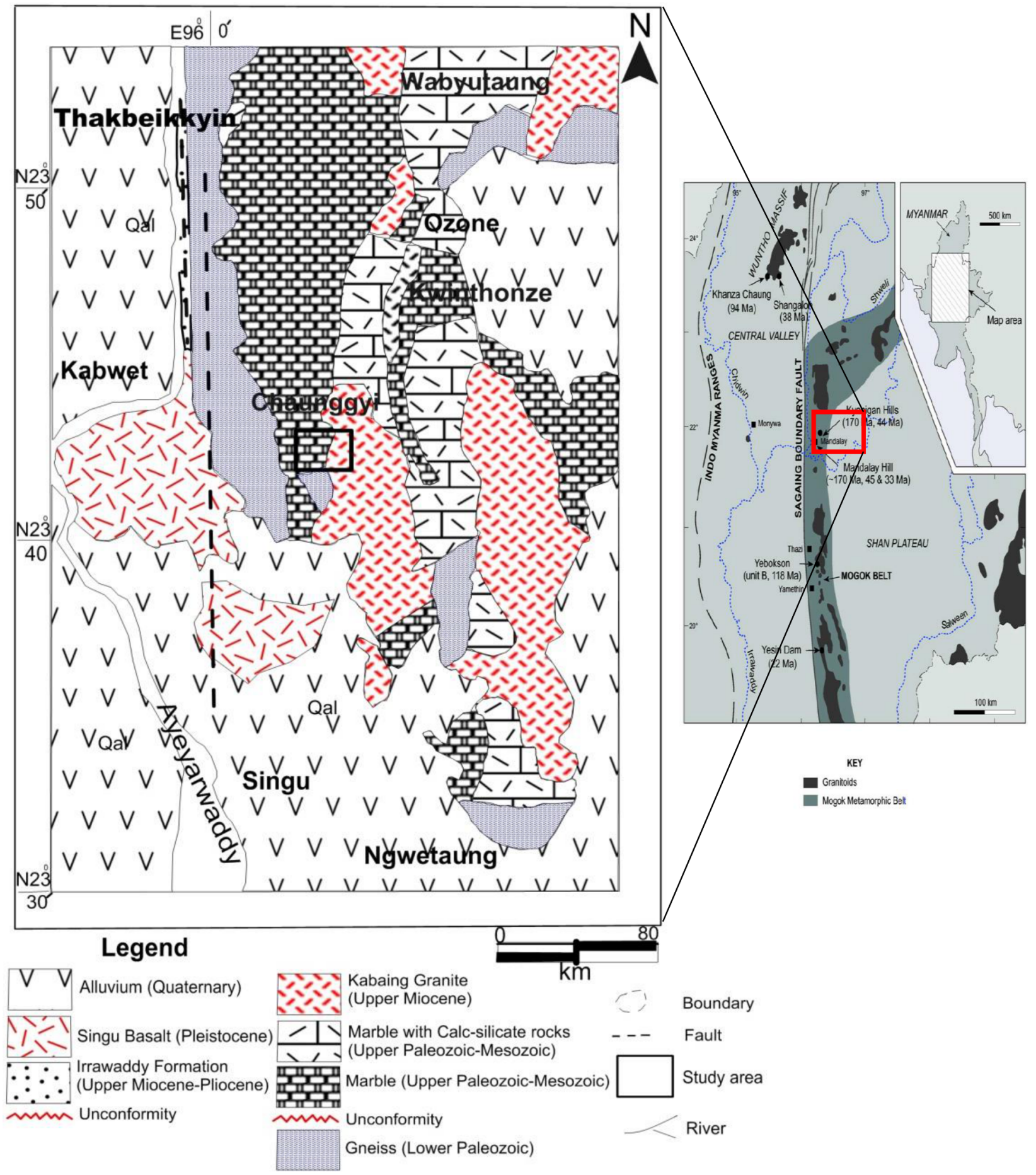

Figure 1: Regional geological map of Mogok Metamorphic Belt (modified from Thein et al., 1990). 

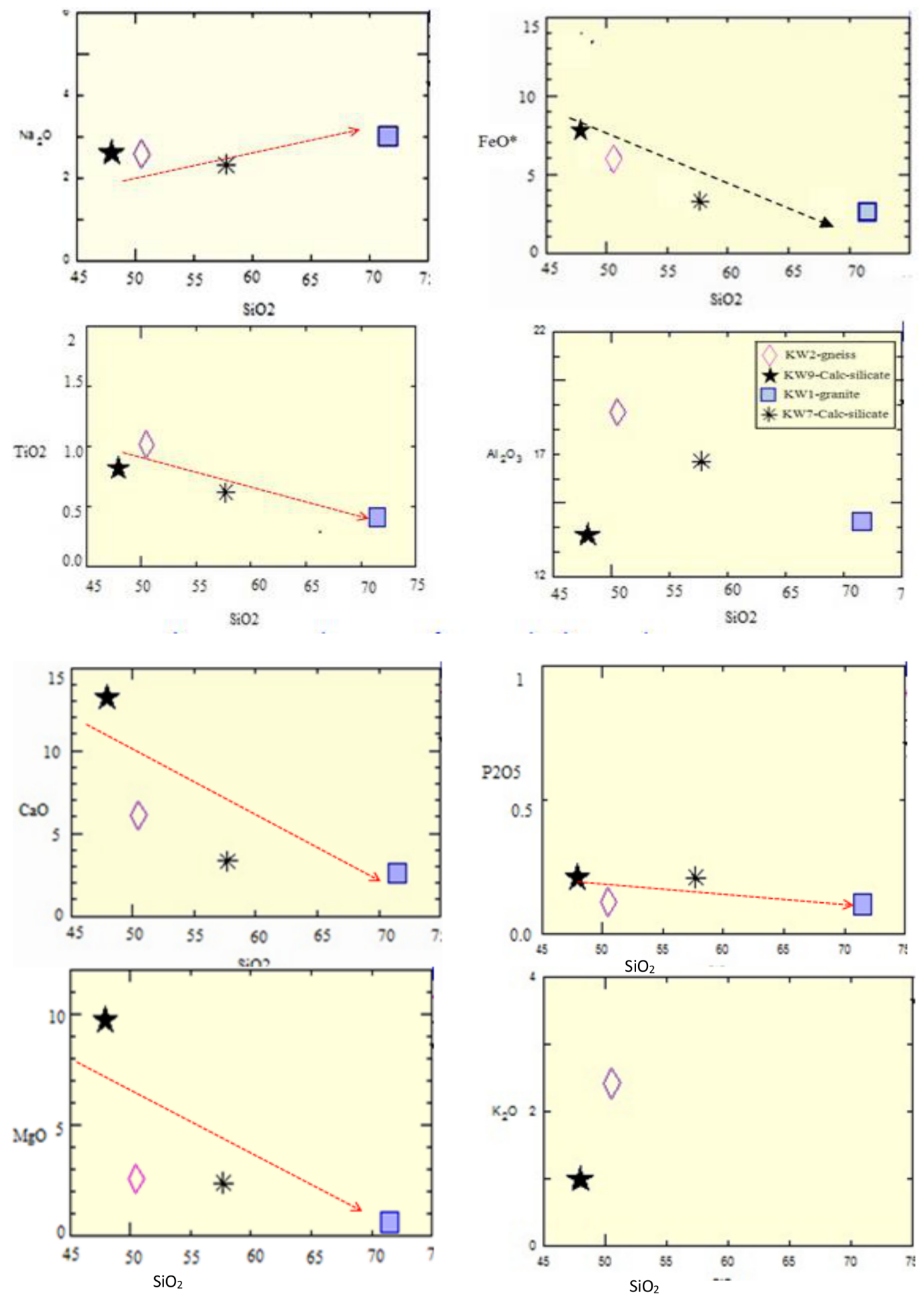

Figure 2: Harker variation diagrams of $\mathrm{SiO}_{2}$ vs $\mathrm{MgO}, \mathrm{SiO}_{2}$ vs FeO, $\mathrm{SiO}_{2}$ vs $\mathrm{Na}_{2} \mathrm{O}, \mathrm{SiO}_{2}$ vs $\mathrm{CaO}, \mathrm{SiO}_{2}$ vs $\mathrm{P}_{2} \mathrm{O}_{5}$. 

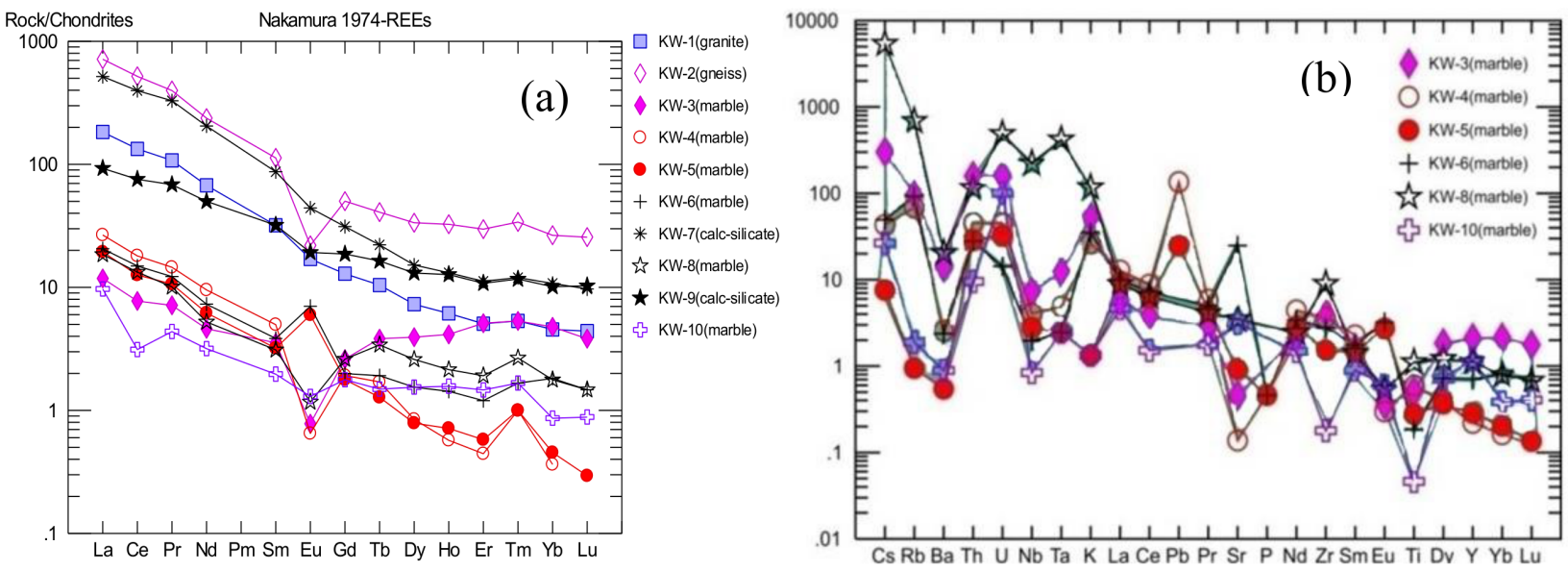

Figure 3: (a) Chondrite-normalized REE patterns of metamorphic rocks from the study area (Nakamura, 1974), (b) Incompatible element patterns of metamorphic rocks (marble) of the study area normalized to primitive mantle. The normalized values of primitive mantle abundances are used by data of Sun and McDonough (1989).

strongly spiked and exhibit complex nature (Figure 3). In the primitive mantle normalized multi-element diagram of marble samples (Figure $3 \mathrm{p}$ ), depletion was observed in the $\mathrm{Rb}, \mathrm{Ba}$, $\mathrm{Nb}, \mathrm{Ta}, \mathrm{Sr}, \mathrm{Zr}$, and $\mathrm{Ti}$ and enrichment was seen in the Th, $\mathrm{U}, \mathrm{K}, \mathrm{Pb}, \mathrm{Nd}$ and $\mathrm{Sm}$. But one marble sample (KW-8) exhibit enrichment of $\mathrm{Nb}$, $\mathrm{Ta}$ and $\mathrm{Zr}$.

\section{Granite geochemistry and petrogenesis}

According to major elements in the granite sample contains the $\mathrm{SiO}_{2}$ composition has 71.5, the $\mathrm{Al}_{2} \mathrm{O}_{3}$ 14.25, the $\mathrm{Fe}_{2} \mathrm{O}_{3}$ 3.35, the $\mathrm{CaO}$ 2.61, the $\mathrm{MgO}$ 0.6, the $\mathrm{Na}_{2} \mathrm{O}$ 3.01, the $\mathrm{K}_{2} \mathrm{O}$ 4.06, the $\mathrm{Cr}_{2} \mathrm{O}_{3}$ $<0.01$, the $\mathrm{TiO}_{2}$ 0.41, the $\mathrm{MnO} 0.04, \mathrm{P}_{2} \mathrm{O}_{5}$ 0.11, the $\mathrm{SrO} 0.05$, the $\mathrm{BaO} 0.14$ and the LOI 0.63. In TAS diagram (Figure 4 a), the samples show the sub-alkaline nature. There is a limitation of number of samples, only one sample of granite is applied in geochemical classification.

In order to observe the alkalinity of the granitic rock in the study area, Shand's Indes is applied for this classification. $\mathrm{A} /(\mathrm{N}+\mathrm{K})$ vs $\mathrm{A} /(\mathrm{C}+\mathrm{N}+\mathrm{K})$ diagram (Figure $4 \mathrm{~b})$ is applied for the classification and the granite sample of the study area which is related to the skarn mineralization shows peraluminous character and classified as I-type granite. $\mathrm{CaO}+\mathrm{Al}_{2} \mathrm{O}_{3}+$ Alkali diagram (Figure 44) also shows the peraluminous character of the granite from the WetheyPheshey area.

Trace element data can also provide a means to determine the tectonic setting. Trace element analyses were used in this study to inves- tigate the tectonic origins of granitic rocks from the study area. Tectonics setting of the granites can be groups into four main settings according to Pearce et al. (1984). They are syncollisional granites (syn-COLG), within-plate granites (WPG), volcanic-arc granites (VAG) and ocean-ridge granites (ORG). Y, Nb, and $\mathrm{Rb}$ are utilized in tectonic discrimination diagrams and are generally considered immobile under most metamorphic conditions Pearce et al. (1984).

On the tectonic discrimination diagram ( $\mathrm{Rb}$ vs $\mathrm{Y}+\mathrm{Nb}$. Pearce et.al., 1984), was selected as the most efficient discriminations between the most types of oceanic-ridge granite (ORG), within plate granite (WPG), volcanic-arc granite (VAG) and syn-collisional granites (syn-COLG). The granite has trace element characteristics of a volcanic-arc setting and plotted on the volcanic arc granite field (Figure $4 \mathrm{~d}$ ). By applying $\mathrm{Nb}-\mathrm{Y}$ discrimination diagram (Figure $4 \mathrm{~d}$ ), the granite was also plotted on the VAG+ syn-COLG field and has the trace elemental nature of volcanicarc setting and syn-collisional granites setting. $\mathrm{Zr}$ vs Ga/Al diagram (Whalen et al., 1987) is used for the classification of granite type.

Based on the binary plot, the granite from the research fall within I+S type fields (Figure 44) Based on geochemical data, it can be concluded that the granite is related to the skarn mineralization and plays as a source rock of the skarn mineralization. 

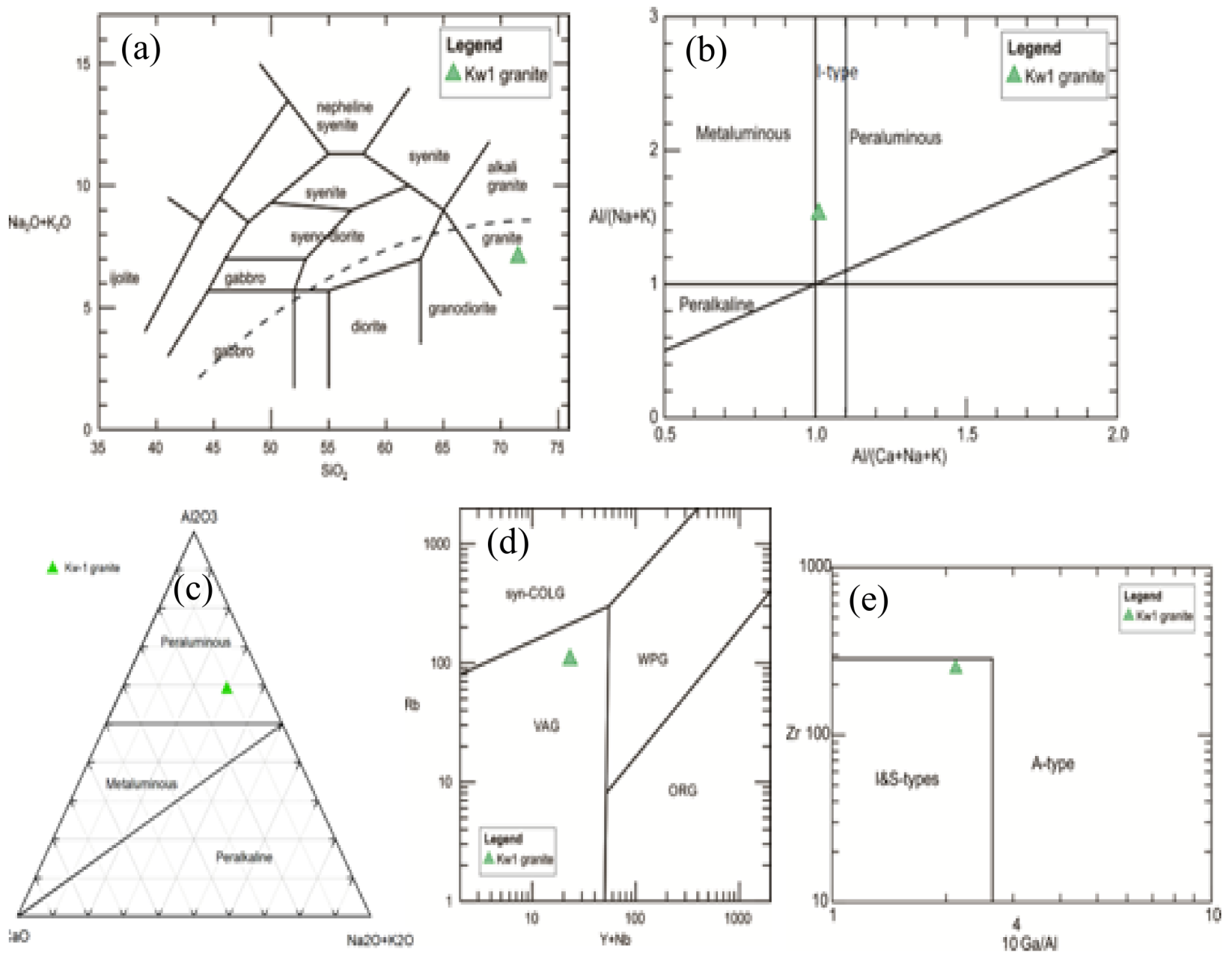

Figure 4: (a) Classification schemes of plutonic igneous rocks (Cox et al., 1979) and a plot of granite sample $(\mathrm{Kw}-1)$ from the study area. (b) $\mathrm{Al} /(\mathrm{N}+\mathrm{K})$ vs $\mathrm{A} /(\mathrm{C}+\mathrm{N}+\mathrm{K})$ diagram for the classification of granite from the study area (Shand, 1943). Division line for the I-type granite is taken from Ilberli (2009). (c) $\mathrm{CaO}+\mathrm{Al}_{2} \mathrm{O}_{3}+\left(\mathrm{Na}_{2} \mathrm{O}+\mathrm{K}_{2} \mathrm{O}\right)$ diagram for the classification of granite from the study area. (d) Tectonic discrimination diagram for granite (after Piearce et al., 1984) showing the fields of syn-collisional granites (syn-COLG), within-plate granites (WPG), volcanic-arc granites (VAG) and ocean-ridge granites (ORG). Granite $(\mathrm{Kw}-1)$ from the study area plot within the VAG granite field. (e) $\mathrm{Zr}$ vs Ga/Al diagram for the classification of granite type (Whalen et al., 1987). 


\subsection{Hydrothermal alteration}

Intense hydrothermal alteration is recognized in the study area. Propylitic alteration occurs in marble and consists of the mineral assemblages of quartz-pyrite-chlorite and quartz-pyritechlorite-illite-albite. Pyrite can be recognized as fine-grained disseminated grains in the propylitic alteration. Argillic alteration zone is characterized by quartz, illite/muscovite, pyrite, and chalcopyrite. This alteration indicates that the dominated mineral assemblage is quartzpyrite illite/muscovite. Skarn (calc-silicate) alterations in the study area include silification, garnetification, pyroxenization and chloritization. Silification is the typical alteration in skarn zone. Prograde skarn alteration is dominated by garnet and amphibole. Chloritization occurs as retrograde alteration related to skarn mineralization.

\subsection{Ore mineralogy}

The main ore minerals consist of galena, pyrite, sphalerite, chalcopyrite minor amount of pyrrothite. Iron oxides contain hematite and goethite. Gangue minerals are quartz and calcite.

Galena occurs associated with chalcopyrite and sphalerite. It is easily recognized by its texture especially creamy white in colour, triangular pits and sized range from 100 to $500 \mu \mathrm{m}$ (Figure $5 \mathrm{a}$ ). The textures show that galena relatively late form with sphalerite.

Pyrite is abundant mineral sulfide and found in all samples. This mineral has euhedral to subhedral form ranges from 10 to $500 \mu \mathrm{m}$ (Figure 5p). Pyrite has dominated association with galena, chalcopyrite and sphalerite. Sometimes, pyrite was found in intergrowth with and /or enclosed in sphalerite.

Sphalerite is associated with galena, chalcopyrite and pyrite. Sphalerites are usually identified as coexist and inclusion in galena (Figure 5k). Some are found as coexist of pyrite and chalcopyrite.

Chalcopyrite is abundant and association with "galena and sphalerites" subhedral to anhedral form; size in range from $100 \mu \mathrm{m}$ to $500 \mu \mathrm{m}$ and have mostly oxided (Figure $5 \mathrm{~d}$ ).

Hematite ore occurs as irregular in shape and vein replacing other minerals such as pyrite and fibrous hedenbergite. Hematite also occurs as small blade. It is light grey-white color with bluish tint and has moderate and reflectivity. It is difficult to polish due to its lamellar texture (Figure 5e). It is generally associated with pyrite, chalcopyrite, cassiterite and sphalerite. Hematite is the most important ore of iron and is also a common alteration mineral.

Goethite is blackish brown or reddish brown in hand specimen. The yellowish brown to orange brown streak distinguishes it from the brownish red streak of hematite. It has low reflectance, distinct anistropism and abundance red orange or yellow internal reflections. Goethite is usually associated with pyrite, sphalerite, galena and hematite. Goethite is a common ore of iron. It typically forms under oxidizing conditions as a weathering product of iron-bearing minerals such as magnetite, pyrite.

Gold is the bright yellow color, resistance to tarnish, metallic luster, hackly fracture, malleability and very high density. It occurs as minute blebs of native gold (Figure 5f). Gold is mostly associated with pyrite, galena, chalcopyrite and sphalerite.

\subsection{Ore geochemistry}

Precious metal, base metal and other trace element composition of the ore samples were performed by ICP-MS and ICP-AES analyses and their result show that strong concentration of gold, silver, copper, lead, and zinc were observed in the samples KW3, KW4, KW5 and KW6. The analyzed samples concentration of gold ranges from 0.014 to $1.465 \mathrm{wt} \%$, silver 5 to $70.5 \%$, copper 264 to $1260 \mathrm{ppm}$, lead $182 \mathrm{ppm}$ to $>1 \%$, zinc $78 \mathrm{ppm}$ to $>1 \%$. The highest concentration of gold and silver was observed in sample KW4 with Au 1.465 ppm and Ag 70.5 ppm (Figure 6).

Multi-elemental plots were performed for some metal and elements (such as $\mathrm{Au}, \mathrm{Ag}, \mathrm{Cu}$, $\mathrm{Pb}$ and $\mathrm{As}$ ) in order to see variation and relation among these elements (Figure 6). Based on the bivariate plot it is clear that Au is positively correlated with As and $\mathrm{Cu}$ (Figure 6). The concentration of the gold in the mineralized ore increases relatively with those of other metals strongly indicates that they are closely associated during the deposition. This is evident by the occurrence of the gold in association with base-metal bearing minerals such as 

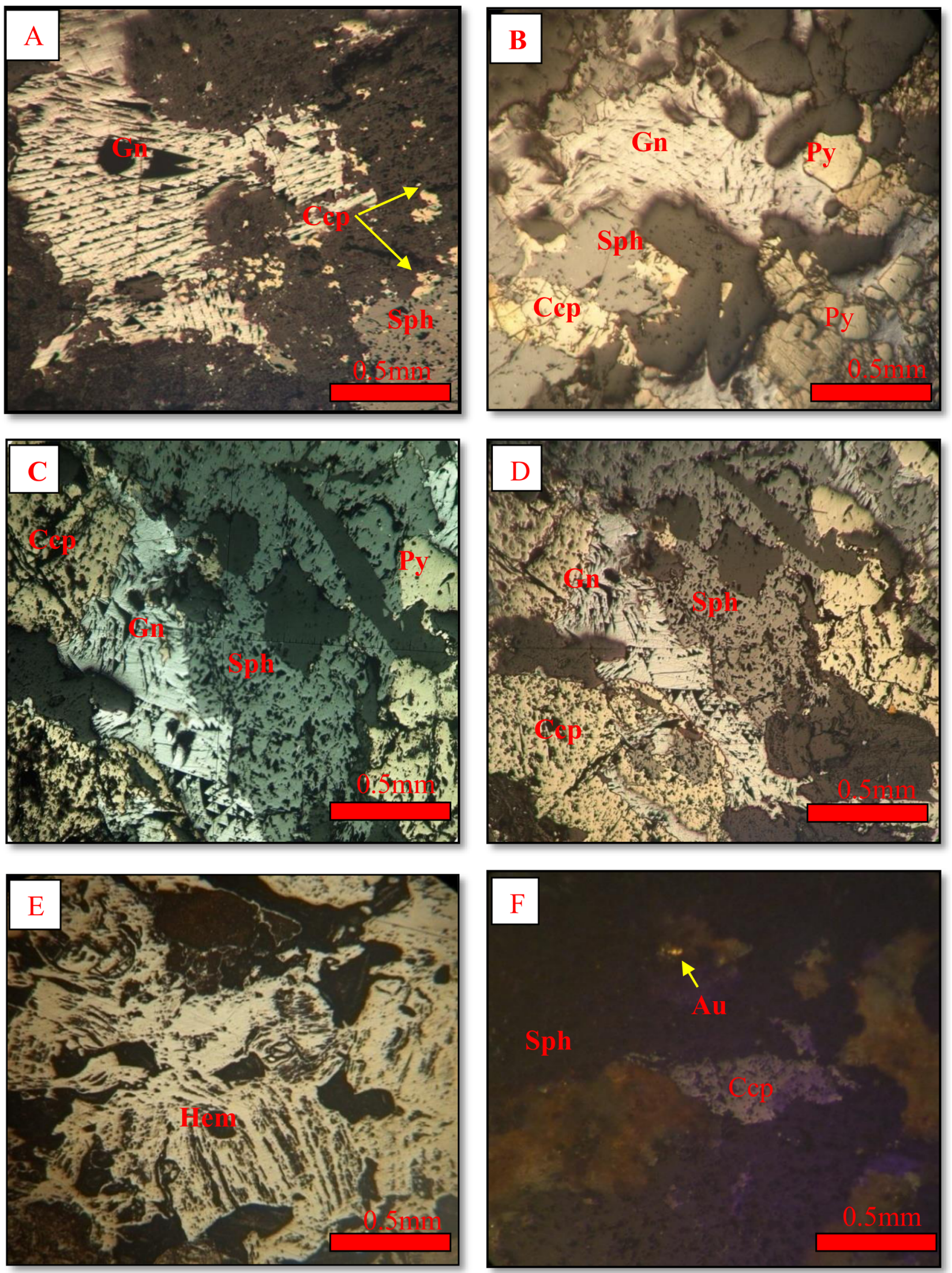

Figure 5: Photomicrograph of ore mineral assemblages from the research area: $\mathrm{Gn}=$ galena, $\mathrm{Ccp}=$ chalcopyrite, $\mathrm{Sph}=$ sphalerite, $\mathrm{Py}=$ pyrite, $\mathrm{Hem}=$ hematite, $\mathrm{Au}=$ gold. 

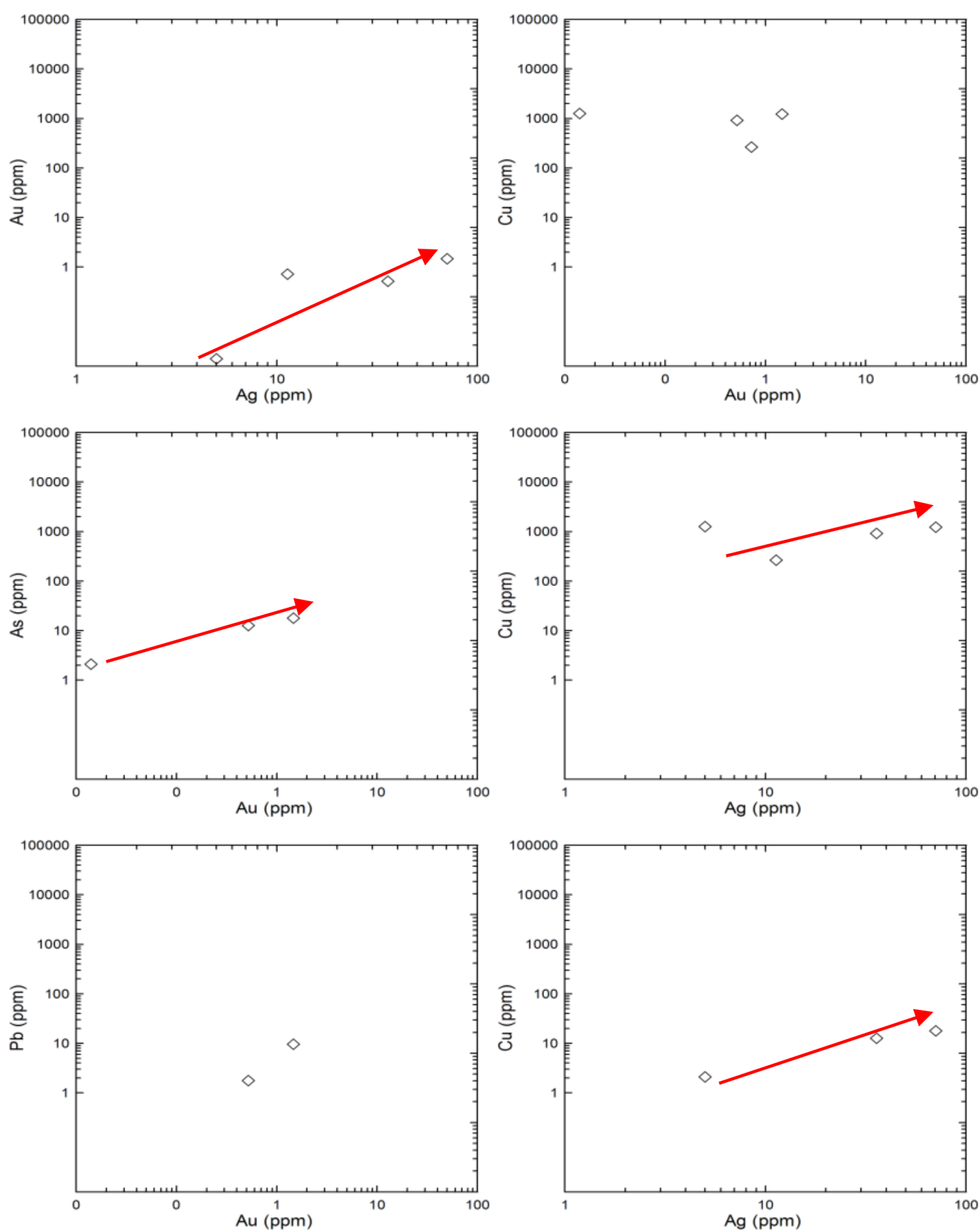

Figure 6: Bivariate multi-element plots of $\mathrm{Au}, \mathrm{Ag}, \mathrm{Cu}, \mathrm{Pb}$, and $\mathrm{As}$ concentration from the research area. 
galena, sphalerite and chalcopyrite in the mineralized ore veins. Correlation between gold and silver with other metal such as zinc and lead are not made in the present study due to limited analysis of number of samples and higher concentration of these elements in the analyzed samples.

\section{CONCLUSION}

Based on the host rocks/associated rocks, types of alteration, geochemical characteristics the skarn mineralizations at Wethey-Pheshey area is identified as intrusion-related, base-metal skarn mineralization. Intrusion of granitic rocks within the carbonate rocks caused the base metal ore mineralization and associated skarn alterations. Granite shows the subalkaline nature and peraluminous character. The granite is identified as I-type granite (magnetite series) developed in the volcanic arc setting. Granite plays as a source rock in the formation of skarn mineralization. Hydrothermal alteration (argillic and propylitic) was probably developed from the hydrothermal event during metamorphism controlled by the geological structures (e.g. faults) which overprint the skarn mineralized system. Skarn mineralization is identified as gold, copper, lead-zinc skarn and the mineral assemblages of marble contain calcite, phlogopite, diopside, garnet, epidote, quartz and plagioclase and type of skarn is defined as calcic exoskarn. The mineralization is associated with sulphides including pyrrhotite, pyrite, sphalerite, galena and chalcopyrite and oxides mineral such as hematite and goethite.

\section{ACKNOWLEDGEMENTS}

The current research is supported by AUN/SEED-Net (JICA) under the Collaborative Research Program on the Integrated Study on Earth Resources within the Island Arc and Continental Margin Geological Setting of SE Asia.

\section{REFERENCES}

Cox, K.G., Bell, J. D., Pankhurst, R.J. (1979) The interpretation of Igneous Rocks. Allen \& Unwin. London.

Nakamura, N. (1974) Determination of REE, Ba, Fe, $\mathrm{Mg}, \mathrm{Na}$ and $\mathrm{K}$ in carbonaceous and oridinary chondrites. Geochim. Cosmochim. Acta, 38, 575775.

Pearce, J.A., Harris, N.B.W. and Tindle, A.G. (1984) Trace element discrimination diagrams for the tectonic interpretation of granitic rocks. Journal of Petrology, 25. Part 4. 956-983.

Searle, D.L., and Haq B.T. (1964) The Mogok Belt of Burma and its relationships to the Himalayan Orogeny, in Proceeding of the 22nd International Geological Conference. Delhi, 11: 132-161.

Sun, S.S., McDonough, W.S. (1989) Chemical and isotopic systematic of oceanic basalts: implications for mantle composition and processes. In: Saunders A.D., Norry M.J (Eds.), Magmatism in the Ocean Basins. Geological Society of London, Special Publication, 313-345.

Swe, W. (1972) Strike-slip faulting in Central Belt of Burma. Paper read at the Fifth Burma Research Congress. Contributions to Burmese Geology. Vol.1, No.1, pp. 63-72.

Thein, M. L., Myint, O., Kyi, S., Win, H. N. (1990) "Geology and Stratigraphy of the Metamorphosed early Palaeozoic Rocks of the MogokThabeikkyin-Singu-Mandalay Areas", Research paper Session II in Communication of Diamond Jubilee, p. 2-3.

Whalen, J.B., Currie, K. L., Chappell, B.W. (1987) A-type granites: Geochemical characteristics, discrimination and petrogenesis. Contrib. Mineral. Petrol., 95, 407-419.

Zaw, K., Sutherland, L., Yui, T.F., Meffre, S., Kyaw Thu (2014) Vanadium-rich ruby and sapphire within Mogok Gemfield, Myanmar: implications for gem color and genesis. Mineralium Deposita, DOI: 10.1007/s00126-014-0545-0. 